\title{
Effects of anions on the biosorption of microelement cations by macroalga Enteromorpha prolifera in single- and multi-metal systems
}

\author{
MICHALAK Izabela* \& CHOJNACKA Katarzyna \\ Institute of Inorganic Technology and Mineral Fertilizers, Wrocław University of Technology, Smoluchowskiego 25, 50-372 Wrocław, Poland
}

Received January 24, 2011; accepted July 4, 2011

\begin{abstract}
The results of research on the effects of anions on the biosorption of microelement cations by the edible marine macroalga Enteromorpha prolifera in single- and multi-metal systems are discussed in this paper. It was shown that the maximum biosorption capacity $\left(q_{\max }\right)$ in a single-metal system of $\mathrm{Co}(\mathrm{II})$ ions decreased in the following sequence: $\mathrm{Cl}^{-}\left(46.0 \mathrm{mg} \mathrm{g}^{-1}\right)>\mathrm{SO}_{4}{ }^{2-}(42.8 \mathrm{mg}$ $\left.\mathrm{g}^{-1}\right)>\mathrm{NO}_{3}^{-}\left(41.9 \mathrm{mg} \mathrm{g}^{-1}\right)$. In multi-metal systems, in which the ratios of $\mathrm{Cl}^{-}, \mathrm{NO}_{3}^{-}$, and $\mathrm{SO}_{4}{ }^{2-}$ were $0: 0: 4,1: 1: 2,3: 0: 1$, and 4:0:0, there were clear differences among the biosorption capacities. In all the examined systems (other than the 0:0:4 system), inhibition of the binding of microelement cations by the macroalga was observed. In all the systems, the highest value of $q_{\max }$ was obtained for $\mathrm{Cu}(\mathrm{II})$ cations; the value ranged from $31.9 \mathrm{mg} \mathrm{g}^{-1}$ in $0: 0: 4\left(\mathrm{SO}_{4}{ }^{2-}\right.$ only) to $18.2 \mathrm{mg} \mathrm{g}^{-1}$ in 4:0:0 ( $\mathrm{Cl}^{-}$only).
\end{abstract}

biosorption, anions, microelement cations, single- and multi-metal systems, Enteromorpha prolifera

Citation: Michalak I, Chojnacka K. Effects of anions on the biosorption of microelement cations by macroalga Enteromorpha prolifera in single- and multi-metal systems. Chin Sci Bull, 2012, 57: 736-743, doi: 10.1007/s11434-011-4924-y

The biosorption of metal ions by algae has been widely reported in the literature. However, the majority of the published work describes single-metal biosorption systems. Very little information is available on multi-metal biosorption systems such as binary [1-5], ternary [1,4-6], and quaternary systems [7]. There is a necessity to perform experiments on such systems because they better reflect real effluents from industrial operations. Another issue, which is often neglected in the literature, is the investigation of the effects of anions on biosorption processes. This aspect should also be taken into consideration because the presence of anions in aqueous solutions could affect metal cation biosorption [8].

In the literature, two aspects of the effects of anions on biosorption processes are considered: the effects of anions on the maximum biosorption capacity in single-metal systems [9], and the effects of anion concentration on the biosorption of several metal ions in multi-metal systems

*Corresponding author (email: izabela.michalak@pwr.wroc.pl)
$[8,10,11]$. It is important to emphasize that the influence of the anion on the biosorption capacity could differ depending on the biomass used and the biosorbed metal ions. The anions $\mathrm{NO}_{3}{ }^{-}$and $\mathrm{SO}_{4}{ }^{2-}$ did not significantly influence the removal efficiency of the fungus Aspergillus niger for $\mathrm{Cr}(\mathrm{VI})$, $\mathrm{Co}(\mathrm{II}), \mathrm{Ni}(\mathrm{II})$, and $\mathrm{Zn}$ (II) ions, whereas the presence of $\mathrm{Cl}^{-}$ anions significantly decreased the efficiency of metal ion biosorption in multi-metal systems [10]. In the case of another fungus, namely Rhizopus arrhizus, the degree of inhibition of the biosorption of $\mathrm{La}(\mathrm{III}), \mathrm{Cd}(\mathrm{II}), \mathrm{Pb}(\mathrm{II})$, and $\mathrm{Ag}(\mathrm{I})$ cations generally followed the order EDTA $>\mathrm{SO}_{4}{ }^{2-}>\mathrm{Cl}^{-}>$ $\mathrm{PO}_{4}{ }^{3-}>$ glutamate $>\mathrm{CO}_{3}{ }^{2-}$ [12]. During biosorption of $\mathrm{Co}(\mathrm{II})$ cations by the brown macroalga Ascophylum nodosum, the presence of $\mathrm{SO}_{4}{ }^{2-}$ and $\mathrm{PO}_{4}{ }^{3-}$ anions did not result in any change in biosorption, in contrast to $\mathrm{NO}_{3}{ }^{-}$anions, which were the strongest inhibitor [13]. The opposite situation was observed in the case of biosorption of $\mathrm{Zn}$ (II) cations by the cyanobacterium Oscillatoria anguistissim, for which the inhibitory order of the anions was as follows: $\mathrm{SO}_{4}{ }^{2-}>\mathrm{Cl}^{-}>$ $\mathrm{NO}_{3}{ }^{-}$(i.e., $\mathrm{SO}_{4}{ }^{2-}$ anions were the strongest inhibitor) [11]. 
As mentioned above, the influence of the anion on biosorption capacity could also differ depending on the metal ions biosorbed; for example, Han et al. [8] observed the following inhibitory orders for the biosorption of $\mathrm{Cr}(\mathrm{VI})$ and $\mathrm{Cr}(\mathrm{III})$ ions, respectively: $\mathrm{NO}_{3}{ }^{-}>\mathrm{Cl}^{-}>\mathrm{SO}_{4}{ }^{2-}$ and $\mathrm{SO}_{4}{ }^{2-}>$ $\mathrm{Cl}^{-} \approx \mathrm{NO}_{3}{ }^{-}$.

In the present paper, these two aspects were taken into consideration to better understand the mechanism of the biosorption of metal ions by Enteromorpha prolifera. This edible marine macroalga, enriched with microelement cations ( $\mathrm{Zn}(\mathrm{II}), \mathrm{Cu}(\mathrm{II}), \mathrm{Co}(\mathrm{II})$, and $\mathrm{Mn}(\mathrm{II})$ ) via biosorption is used as a biological, mineral feed additive for livestock. Previous experiments on the kinetics and equilibrium of the biosorption revealed that this process is complex and depends not only on the process parameters such as $\mathrm{pH}$, temperature, biomass concentration, and concentration of metal ion $[14,15]$, but also on the physicochemical properties of the metal ions, properties of the biosorbent, and probably on the presence of competing metal ions and the types of anions. For the application of the biosorption process on an industrial scale, detailed experiments are required. The main goal of this paper was to determine whether the type of anion and its concentration in aqueous solution influences the amount of metal cations bound by the Enteromorpha prolifera biomass. The biosorption of microelement cations was carried out in single- and multi-metal systems. In the single-metal system, the effects of anions $\left(\mathrm{Cl}^{-}, \mathrm{NO}_{3}{ }^{-}\right.$, and $\mathrm{SO}_{4}{ }^{2-}$ ) on biosorption of $\mathrm{Co}(\mathrm{II})$ cations were checked. As an example of a multi-metal system, a quaternary-metal system was chosen because, from the economic point of view, it is beneficial to enrich macroalgal biomass simultaneously with all the cations essential for animals ( $\mathrm{Cu}(\mathrm{II}), \mathrm{Zn}(\mathrm{II})$, $\mathrm{Co}(\mathrm{II})$, and $\mathrm{Mn}(\mathrm{II}))$. These experiments allowed us to determine not only the effects of anions and their concentrations on biosorption performance, but also to investigate the competition between microelement cations for cation binding sites on the surface of macroalgal cells.

\section{$1 \quad$ Materials and methods}

\subsection{Sorbent preparation}

The alga Enteromorpha prolifera was collected from the
Baltic Sea (Niechorze, Poland). It was identified at the Department of Botany and Plant Ecology of Wrocław University of Environmental and Life Sciences. The collected algal biomass was washed with tap water several times to remove foreign matter, and then three times with deionized water. The biomass was then dried at $60^{\circ} \mathrm{C}$ until a constant mass was reached (to ensure there would be no bioaccumulation process). The biomass of dry alga was ground and used in biosorption experiments.

\subsection{Batch biosorption experiments}

The biosorption experiments were performed in Erlenmeyer flasks containing $20 \mathrm{~mL}$ of microelement cation solution in a thermostated water bath shaken at $100 \mathrm{r} / \mathrm{min}$ using the single- and multi-metal systems shown in Table 1.

In the first system (No.1) the concentration of $\mathrm{Co}$ (II) cations (chosen as an example) ranged from 25 to $400 \mathrm{mg}$ $\mathrm{L}^{-1}$. In the multi-metal systems, the concentration of each cation, i.e., $\mathrm{Cu}(\mathrm{II}), \mathrm{Zn}(\mathrm{II}), \mathrm{Co}(\mathrm{II})$, and $\mathrm{Mn}$ (II) in the solution was the same. In systems No.2 and No.3, the concentrations ranged from 1 to $100 \mathrm{mg} \mathrm{L}^{-1}: 1,5,10,20,30,40,60,80$, and $100 \mathrm{mg} \mathrm{L}^{-1}$ (the sums of all cations in the solution, i.e., from 0.0838 to $8.23 \mathrm{mmol} \mathrm{L}^{-1}$ and from 0.0810 to 7.91 mmol L ${ }^{-1}$, respectively). In systems No.4 and No.5 the concentrations ranged from 20 to $100 \mathrm{mg} \mathrm{L}-1: 20,30,40,50,60$, 80,90 , and $100 \mathrm{mg} \mathrm{L}^{-1}$ (the sums of all cations in the solution, i.e., from 1.41 to $7.03 \mathrm{mmol} \mathrm{L}^{-1}$ and from 1.50 to 7.47 mmol L ${ }^{-1}$, respectively). For the interpretation of the results, it was assumed that in multi-metal systems the anions were arranged in the following order: $\mathrm{Cl}^{-}, \mathrm{NO}_{3}{ }^{-}, \mathrm{SO}_{4}{ }^{2-}$ and the ratios of anions were as follows, 0:0:4 (No.2), 1:1:2 (No.3), 3:0:1 (No.4), and 4:0:0 (No.5).

The microelement solutions were prepared in deionized water by dissolving appropriate amounts of inorganic salts: $\mathrm{CoSO}_{4} \cdot 7 \mathrm{H}_{2} \mathrm{O}, \mathrm{CoCl}_{2} \cdot 6 \mathrm{H}_{2} \mathrm{O}, \mathrm{Co}\left(\mathrm{NO}_{3}\right)_{2} \cdot 6 \mathrm{H}_{2} \mathrm{O}, \mathrm{CuSO}_{4} \cdot 5 \mathrm{H}_{2} \mathrm{O}$, $\mathrm{CuCl}_{2} \cdot 2 \mathrm{H}_{2} \mathrm{O}, \mathrm{ZnSO}_{4} \cdot 7 \mathrm{H}_{2} \mathrm{O}, \mathrm{ZnCl}_{2}, \mathrm{MnSO}_{4} \cdot \mathrm{H}_{2} \mathrm{O}$, and $\mathrm{MnCl}_{2} \cdot 4 \mathrm{H}_{2} \mathrm{O}$ (POCh S.A., Gliwice, Poland). All these inorganic salts are accepted for use as inorganic mineral feed additives under the relevant regulations. The $\mathrm{pH}$ values of the solutions were adjusted with a $0.1 \mathrm{~mol} \mathrm{~L}^{-1}$ solution of $\mathrm{NaOH} / \mathrm{HCl}$ (POCh S.A.) to 5.0. The $\mathrm{pH}$ was measured using a Mettler-Toledo pH-meter (Seven Multi, Greifensee,

Table 1 Biosorption experiments scheme

\begin{tabular}{|c|c|c|c|c|c|c|}
\hline Microelement & Number & $\mathrm{Cu}(\mathrm{II})$ & $\mathrm{Zn}(\mathrm{II})$ & $\mathrm{Co}(\mathrm{II})$ & $\mathrm{Mn}(\mathrm{II})$ & $\begin{array}{c}\text { Anions ratio } \\
\left(\mathrm{Cl}^{-}: \mathrm{NO}_{3}{ }^{-}: \mathrm{SO}_{4}{ }^{2-}\right)\end{array}$ \\
\hline \multirow{3}{*}{ Single-metal system } & \multirow{3}{*}{1} & \multirow{3}{*}{-} & \multirow{3}{*}{-} & $\mathrm{CoCl}_{2}$ & & $1: 0: 0$ \\
\hline & & & & $\mathrm{Co}\left(\mathrm{NO}_{3}\right)_{2}$ & - & $0: 1: 0$ \\
\hline & & & & $\mathrm{CoSO}_{4}$ & & $0: 0: 1$ \\
\hline \multirow{3}{*}{ Quaternary-metal system } & 2 & $\mathrm{CuSO}_{4}$ & $\mathrm{ZnSO}_{4}$ & $\mathrm{CoSO}_{4}$ & $\mathrm{MnSO}_{4}$ & $0: 0: 4$ \\
\hline & 3 & $\mathrm{CuCl}_{2}$ & $\mathrm{ZnSO}_{4}$ & $\mathrm{Co}\left(\mathrm{NO}_{3}\right)_{2}$ & $\mathrm{MnSO}_{4}$ & $1: 1: 2$ \\
\hline & 5 & $\mathrm{CuCl}_{2}$ & $\mathrm{ZnCl}_{2}$ & $\mathrm{CoCl}_{2}$ & $\mathrm{MnCl}_{2}$ & $4: 0: 0$ \\
\hline
\end{tabular}


Switzerland) equipped with an InLab413 electrode, with temperature compensation. The contact time had previously been evaluated from kinetic experiments as $4 \mathrm{~h}$ [14]. The biomass concentration was $1.0 \mathrm{~g} \mathrm{~L}^{-1}$.

\subsection{Analytical methods}

The concentrations of metal cations in the solutions before and after the biosorption process were determined by ICP-OES (Inductively Coupled Plasma-optical Emission Spectrometry; Varian VISTA-MPX, Australia) in the Laboratory of Multielemental Analyses at Wrocław University of Technology, which is accredited by the International Laboratory Accreditation Cooperation-Mutual Recognition Arrangement (ILAC-MRA) and the Polish Center for Accreditation (PCA) (No.AB 696). For the preparation of standard solutions $\left(1.0,10,50\right.$, and $\left.100 \mathrm{mg} \mathrm{L}^{-1}\right)$ a multielemental standard (100 mg L ${ }^{-1}$ Astasol $®$, Prague, Czech Republic) was used. The samples were analyzed three times and the standard deviations of the measurements did not exceed $5 \%$ [16].

\subsection{Statistical analysis}

Statistical analysis of the experimental data was performed with the STATISTICA (v.8) software (StatSoft, Cracow, Poland).

\section{Results and discussion}

\subsection{Biosorption in single-metal systems}

The Langmuir eq. (1) was used to model the equilibrium between metal ions adsorbed on the biomass and metal ions in the solution at a given temperature [17]:

$$
q_{\mathrm{eq}}=\frac{q_{\mathrm{max}} b C_{\mathrm{eq}}}{1+b C_{\mathrm{eq}}},
$$

where $q_{\text {eq }}$ is the mass of metal ions adsorbed per gram of biomass at equilibrium $\left(\mathrm{mg} \mathrm{g}^{-1}\right), C_{\mathrm{eq}}$ is the residual equilibrium metal ions concentration in the solution $\left(\mathrm{mg} \mathrm{L}^{-1}\right), q_{\max }$ is the maximum possible mass of metal ions adsorbed per gram of adsorbent $\left(\mathrm{mg} \mathrm{g}^{-1}\right)$, and $b$ is a constant related to the affinities of binding sites for the metal ions $\left(\mathrm{L} \mathrm{mg}^{-1}\right)$. Figure 1 shows the influence of the salt anion on the biosorption of Co(II) cations in a single-metal system by Enteromorpha prolifera.

From Figure 1, it can be seen that different anions of Co(II) salts did not significantly influence the biosorption capacity of the macroalga. The highest maximum biosorption capacity, qmax (calculated using the Langmuir equation), was obtained for $\mathrm{CoCl}_{2} \cdot 6 \mathrm{H}_{2} \mathrm{O}, 46.0 \mathrm{mg} \mathrm{g}{ }^{-1}$, then for Co$\mathrm{SO}_{4} \cdot 7 \mathrm{H}_{2} \mathrm{O}, 42.8 \mathrm{mg} \mathrm{g}^{-1}$, and finally for $\mathrm{Co}\left(\mathrm{NO}_{3}\right)_{2} \cdot 6 \mathrm{H}_{2} \mathrm{O}$, $41.9 \mathrm{mg} \mathrm{g}^{-1}$. The average affinity $(b)$ of the macroalgal biomass towards $\mathrm{Co}(\mathrm{II})$ cations was $(0.062 \pm 0.003) \mathrm{L} \mathrm{mg}^{-1}$.

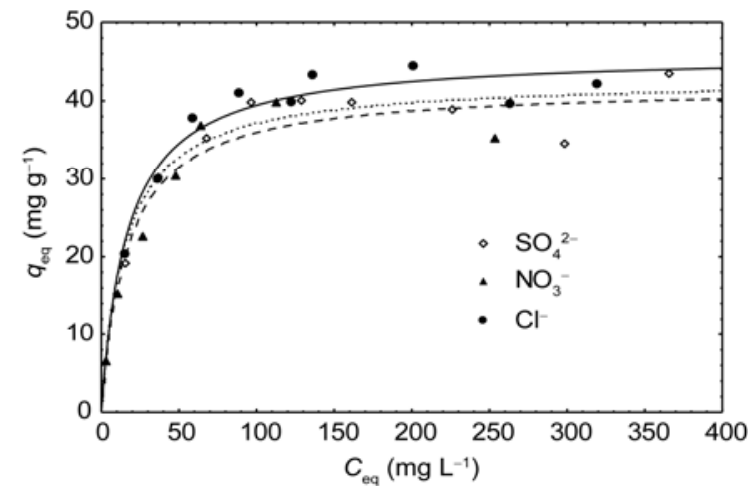

Figure 1 Influence of anion on the biosorption of $\mathrm{Co}(\mathrm{II})$ cations in single-metal system (No.1).

To check whether the values of $q_{\max }$ for $\mathrm{Co}$ (II) cations differed significantly among the examined groups $\left(\mathrm{Cl}^{-}, \mathrm{NO}_{3}{ }^{-}\right.$, and $\mathrm{SO}_{4}{ }^{2-}$ ), the variation coefficient (VC) was calculated and it was equal $4.95 \%$. VC was less than $10 \%$, so the difference was not statistically significant [18]. This was also confirmed by the application of Tukey's test. The $P$ values were as follows: 0.940 for $\mathrm{Cl}^{-} / \mathrm{SO}_{4}{ }^{2-}, 0.577$ for $\mathrm{Cl}^{-} / \mathrm{NO}_{3}{ }^{-}$, and 0.779 for $\mathrm{SO}_{4}{ }^{2-} / \mathrm{NO}_{3}{ }^{-}$; it was assumed that for statistically significant differences $P<0.05$.

However, the influence of the anion on the biosorption capacity could differ depending on the type of biomass used and the metal ions biosorbed because the mechanisms differ. Pulsawat et al. [9] showed that $q_{\max }$ of microbial extracellular polymeric substances (EPS) towards $\mathrm{Mn}$ (II) cations decreased in the sequence $\mathrm{SO}_{4}{ }^{2-}\left(62.4 \mathrm{mg} \mathrm{g}^{-1}\right)>\mathrm{NO}_{3}{ }^{-}(52.5$ $\left.\mathrm{mg} \mathrm{g}^{-1}\right)>\mathrm{Cl}^{-}\left(20.5 \mathrm{mg} \mathrm{g}^{-1}\right)$.

\subsection{Biosorption in multi-metal systems}

The experiments on the biosorption of the microelement cations $\mathrm{Cu}(\mathrm{II}), \mathrm{Zn}(\mathrm{II}), \mathrm{Co}(\mathrm{II})$, and $\mathrm{Mn}$ (II) in multi-metal systems were performed according to the scheme presented in Table 1. The systems differ not only in the types of anions, but also in the total anion concentration in the solution. The first system contained four $\mathrm{SO}_{4}{ }^{2-}$, the second contained two $\mathrm{SO}_{4}{ }^{2-}$, one $\mathrm{Cl}^{-}$, and one $\mathrm{NO}_{3}{ }^{-}$, the third contained three $\mathrm{Cl}^{-}$and one $\mathrm{SO}_{4}{ }^{2-}$, and the fourth contained four $\mathrm{Cl}^{-}$. The biosorption isotherms of the examined microelement cations from salts with different anions are presented in Figure 2.

In all the examined systems (except No.2), inhibition of biosorption, especially of $\mathrm{Co}(\mathrm{II}), \mathrm{Zn}$ (II), and $\mathrm{Mn}$ (II) cations, was observed. To describe the experimental data, a modified Langmuir model with inhibition (2) was proposed:

$$
q_{\mathrm{eq}}=\frac{q_{\mathrm{max}} b C_{\mathrm{eq}}}{1+b C_{\mathrm{eq}}+\frac{C_{\mathrm{eq}}^{2}}{K_{\mathrm{i}}}},
$$

where $\mathrm{Ki}$ is the inhibition constant (mg L-1). This is a simple, empirical model, with one additional constant, $K_{\mathrm{i}}$, which enables us to model biosorption in multi-metal systems 

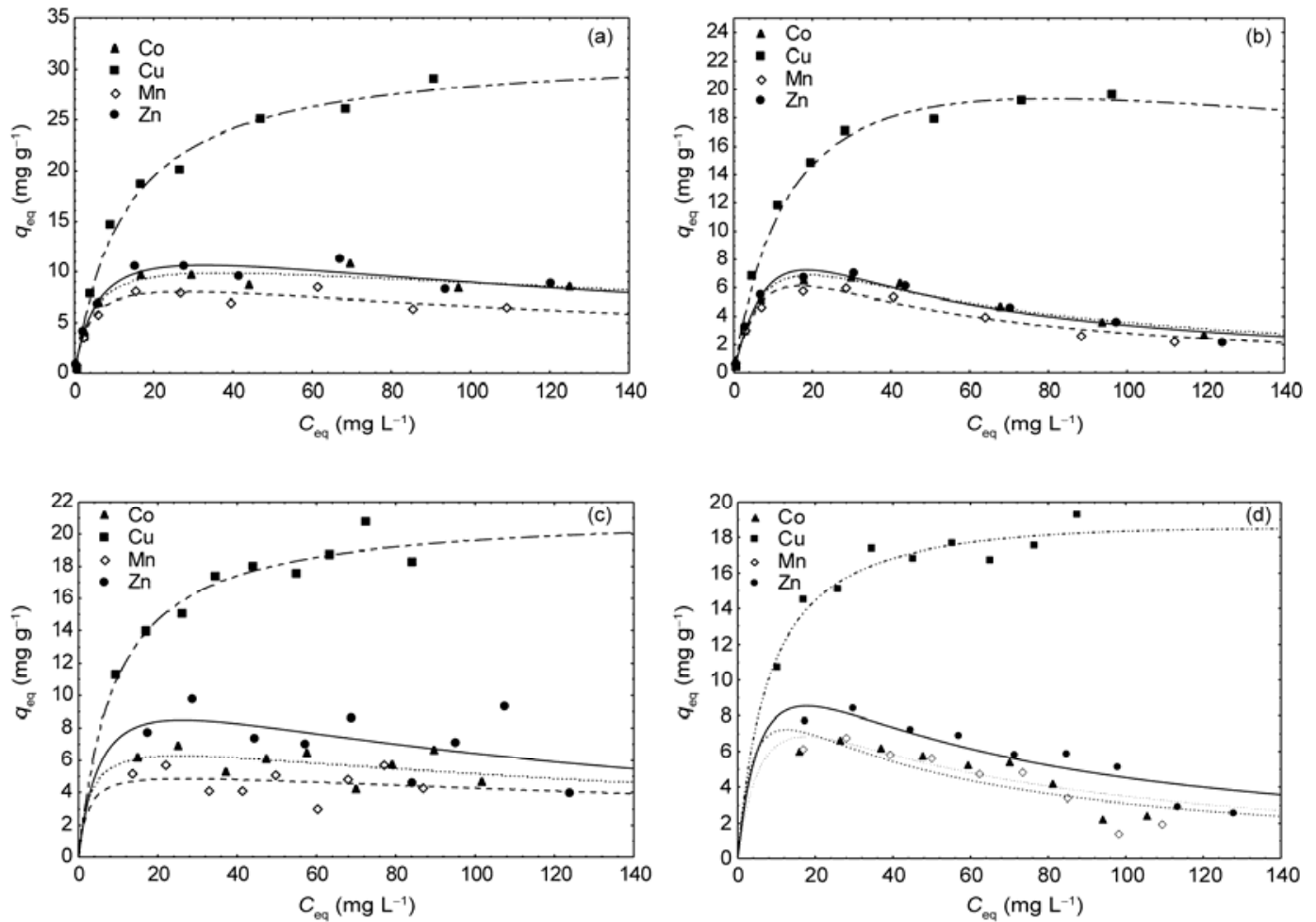

Figure 2 Biosorption isotherms of microelement cations from salts with different anions in multi-metal systems: (a) $\mathrm{No}_{2}\left(\mathrm{Cl}^{-}: \mathrm{NO}_{3}{ }^{-}: \mathrm{SO}_{4}{ }^{2-}=0: 0: 4\right) ;(\mathrm{b})$ No.3 $\left(\mathrm{Cl}^{-}: \mathrm{NO}_{3}{ }^{-}: \mathrm{SO}_{4}{ }^{2-}=1: 1: 2\right)$; (c) No.4 $\left(\mathrm{Cl}^{-}: \mathrm{NO}_{3}{ }^{-}: \mathrm{SO}_{4}{ }^{2-}=3: 0: 1\right) ;$ (d) No.5 $\left(\mathrm{Cl}^{-}: \mathrm{NO}_{3}{ }^{-}: \mathrm{SO}_{4}{ }^{2-}=4: 0: 0\right)$.

where competition between metal cations for binding sites on the surface of macroalgal cell-walls occurs. The higher the value of $K_{\mathrm{i}}$, the smaller the inhibition of the binding of metal cations by the macroalga is.

The biosorptions of all the microelement cations in system No.2 and of $\mathrm{Cu}(\mathrm{II})$ cations in systems Nos.3, 4, and 5 were determined by the conventional Langmuir equation (1) to compare these two models. The parameters of the Langmuir model with inhibition and those of the Langmuir model are presented in Table 2.

Higher values of $R^{2}$ were obtained using the Langmuir model with inhibition; however, the $q_{\max }$ values for the microelement cations determined using the Langmuir equation in system No.2 and for $\mathrm{Cu}$ (II) cations in the other systems better reflect the experimental data. Figure 3 presents the biosorption isotherms for different values of $K_{\mathrm{i}}$.

For the examined microelement ions, where inhibition of biosorption was observed, the order of $K_{\mathrm{i}}$ in all the systems was identical: $(0: 0: 4)>(3: 0: 1)>(1: 1: 2)>(4: 0: 0)$.

To find the correlations between the parameters in the Langmuir equation and inhibition, a correlation matrix was performed Table 3.

Statistical analysis revealed statistically significant correlations $(P<0.05)$ : antagonism for $b \mathrm{Zn}-q_{\max } \mathrm{Zn}(-0.969)$, $b \mathrm{Mn}-q_{\max } \mathrm{Mn}(-0.984), b \mathrm{Co}-q_{\max } \mathrm{Co}(-0.976), b \mathrm{Mn}-q_{\max } \mathrm{Co}$ $(-0.989)$, and $b \mathrm{Co}-q_{\max } \mathrm{Mn}(-0.992)$, and synergism for $b \mathrm{Mn}-b \mathrm{Co}(0.956), K_{\mathrm{i}} \mathrm{Co}-K_{\mathrm{i}} \mathrm{Cu}(0.978)$, and $K_{\mathrm{i}} \mathrm{Co}-K_{\mathrm{i}} \mathrm{Zn}$ (0.979). Statistically significant correlations $(P<0.1)$ were also determined for antagonism for $b \mathrm{Mn}-q_{\max } \mathrm{Zn}(-0.939)$, and synergism for $q_{\max } \mathrm{Mn}-q_{\max } \mathrm{Zn} \quad(0.907), K_{\mathrm{i}} \mathrm{Zn}-K_{\mathrm{i}} \mathrm{Cu}$ (0.917), and $K_{\mathrm{i}} \mathrm{Mn}-K_{\mathrm{i}} \mathrm{Zn}(0.907)$. Generally, the higher the value of $q_{\max }$, the lower $b$ is (for $\mathrm{Zn}(\mathrm{II}), \mathrm{Mn}(\mathrm{II})$, and $\mathrm{Co}$ (II) cations).

Additionally, statistically significant differences in the $q_{\max }$ values of microelement cations were confirmed by Tukey's test. The obtained results are presented in Table 4. For all examined microelement cations, statistically significant differences were observed between systems Nos.2 and 5 .

In all examined systems, the order of the maximum biosorption capacity of Enteromorpha prolifera towards the examined microelement cations was as follows: $\mathrm{Cu}$ (II) $>$ $\mathrm{Zn}(\mathrm{II})>\mathrm{Co}(\mathrm{II})>\mathrm{Mn}(\mathrm{II})$. To choose the best system, the $q_{\text {max }}$ values of each cation in the studied systems were compared; the orders are as follows: $\mathrm{Cu}(\mathrm{II})$, No.2 > No.3 > No.4 >No.5; Zn(II), No.3 > No.5 > No.2 > No.4; Co(II), No. $3>$ No. $5>$ No. $2>$ No. 4 ; Mn(II), No. $3>$ No. $5>$ No. $2>$ No.4. These results showed that the same order was obtained for the cations whose biosorptions were inhibited, i.e., $\mathrm{Zn}(\mathrm{II}), \mathrm{Co}(\mathrm{II})$, and $\mathrm{Mn}(\mathrm{II})$. The best results were obtained in a system with different anions, namely No.3 $\left(\mathrm{Cl}^{-}: \mathrm{NO}_{3}{ }^{-}\right.$: $\left.\mathrm{SO}_{4}{ }^{2-}=1: 1: 2\right)$, and the worst in a system where $\mathrm{Cl}^{-}$anions dominated, namely No.4 $\left(\mathrm{Cl}^{-}: \mathrm{NO}_{3}{ }^{-}: \mathrm{SO}_{4}{ }^{2-}=3: 0: 1\right)$. Moreover, the sum of bound microelement cations was the highest in No.3: $1.25 \mathrm{mmol} \mathrm{g}^{-1}$, followed by the sums in No.2: $1.12 \mathrm{mmol} \mathrm{g}^{-1}$, No.5: $1.03 \mathrm{mmol} \mathrm{g}^{-1}$, and No.4: 0.761 $\mathrm{mmol} \mathrm{g}{ }^{-1}$. 
Table 2 Parameters of Langmuir equation with inhibition and of Langmuir equation for biosorption of microelement cations from quaternary-metal systems

\begin{tabular}{|c|c|c|c|c|c|c|c|c|}
\hline \multirow{2}{*}{ No. } & \multirow{2}{*}{ System } & \multicolumn{4}{|c|}{ Langmuir with inhibition } & \multicolumn{3}{|c|}{ Langmuir } \\
\hline & & $q_{\max }\left(\mathrm{mg} \mathrm{g}^{-1}\right)$ & $b\left(\mathrm{~L} \mathrm{mg}^{-1}\right)$ & $K_{\mathrm{i}}\left(\mathrm{mg} \mathrm{L}^{-1}\right)$ & $R^{2}$ & $q_{\max }\left(\mathrm{mg} \mathrm{g}^{-1}\right)$ & $b\left(\mathrm{~L} \mathrm{mg}^{-1}\right)$ & $R^{2}$ \\
\hline \multirow{4}{*}{2} & $\mathrm{CuSO}_{4}$ & 31.9 & 0.0777 & $8.45 \times 10^{8}$ & 0.997 & 31.9 & 0.0777 & 0.997 \\
\hline & $\mathrm{ZnSO}_{4}$ & 14.6 & 0.163 & 1080 & 0.993 & 10.3 & 0.360 & 0.981 \\
\hline & $\mathrm{CoSO}_{4}$ & 12.3 & 0.217 & 1382 & 0.994 & 9.8 & 0.382 & 0.988 \\
\hline & $\mathrm{MnSO}_{4}$ & 10.4 & 0.244 & 772 & 0.993 & 7.8 & 0.493 & 0.983 \\
\hline \multirow{4}{*}{3} & $\mathrm{CuCl}_{2}$ & 26.9 & 0.0637 & 6452 & 0.997 & 22.5 & 0.0872 & 0.996 \\
\hline & $\mathrm{ZnSO}_{4}$ & 20.3 & 0.0597 & 345 & 0.995 & - & - & - \\
\hline & $\mathrm{Co}\left(\mathrm{NO}_{3}\right)_{2}$ & 15.1 & 0.0875 & 366 & 0.996 & - & - & - \\
\hline & $\mathrm{MnSO}_{4}$ & 14.5 & 0.0872 & 283 & 0.995 & - & - & - \\
\hline \multirow{4}{*}{4} & $\mathrm{CuCl}_{2}$ & 21.4 & 0.109 & $7.41 \times 10^{7}$ & 0.998 & 21.4 & 0.109 & 0.998 \\
\hline & $\mathrm{ZnCl}_{2}$ & 12.4 & 0.166 & 690 & 0.956 & - & - & - \\
\hline & $\mathrm{CoCl}_{2}$ & 7.76 & 0.332 & 634 & 0.982 & - & - & - \\
\hline & $\mathrm{MnSO}_{4}$ & 5.65 & 0.444 & 739 & 0.971 & - & - & - \\
\hline \multirow{4}{*}{5} & $\mathrm{CuCl}_{2}$ & 20.6 & 0.120 & 21101 & 0.998 & 19.9 & 0.132 & 0.998 \\
\hline & $\mathrm{ZnCl}_{2}$ & 15.9 & 0.131 & 314 & 0.985 & - & - & - \\
\hline & $\mathrm{CoCl}_{2}$ & 13.6 & 0.115 & 309 & 0.980 & - & - & - \\
\hline & $\mathrm{MnCl}_{2}$ & 12.8 & 0.208 & 156 & 0.971 & - & - & - \\
\hline
\end{tabular}
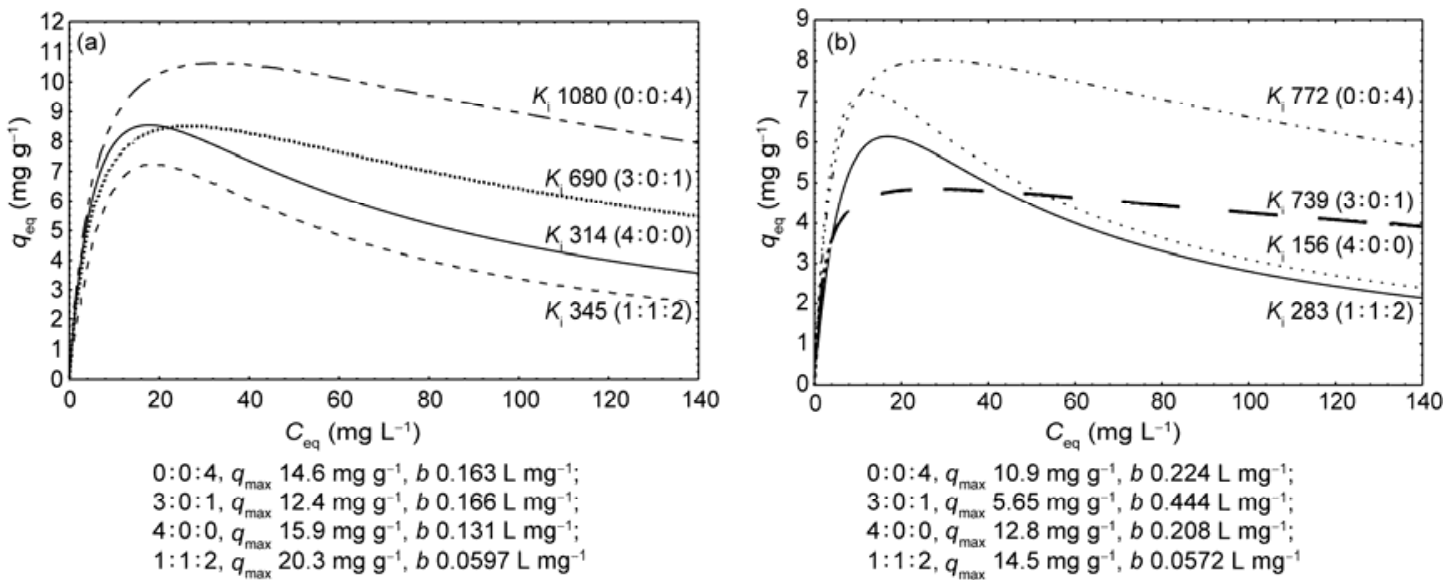

$0: 0: 4, q_{\text {max }} 10.9 \mathrm{mg} \mathrm{g}^{-1}, b 0.224 \mathrm{~L} \mathrm{mg}^{-1}$;

$3: 0: 1, q_{\max } 5.65 \mathrm{mg} \mathrm{g}^{-1}, b 0.444 \mathrm{~L} \mathrm{mg}^{-1}$

$4: 0: 0, q_{\max } 12.8 \mathrm{mg} \mathrm{g}^{-1}, b 0.208 \mathrm{~L} \mathrm{mg}^{-1}$

$1: 1: 2, q_{\max } 14.5 \mathrm{mg} \mathrm{g}^{-1}, b 0.0572 \mathrm{~L} \mathrm{mg}^{-1}$

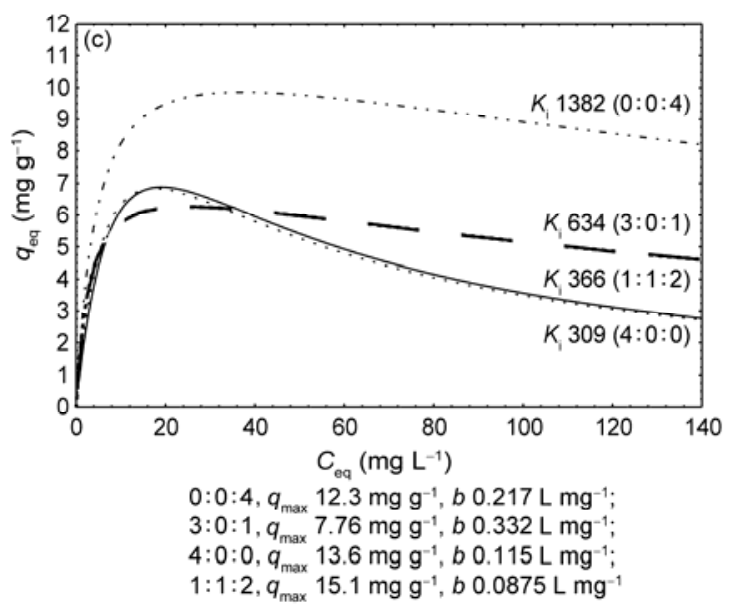

Figure 3 Value of inhibition constants for biosorption of (a) $\mathrm{Zn}(\mathrm{II})$, (b) $\mathrm{Mn}$ (II), and (c) $\mathrm{Co}$ (II) ions in multi-metal systems. 
Table 3 Correlation matrix for parameters of Langmuir equation with inhibition $(N=4)^{\text {a) }}$

\begin{tabular}{|c|c|c|c|c|c|c|c|c|c|c|c|c|}
\hline & $q_{\max } \mathrm{Cu}$ & $q_{\max } \mathrm{Zn}$ & $q_{\max } \mathrm{Co}$ & $q_{\max } \mathrm{Mn}$ & $b \mathrm{Cu}$ & $b \mathrm{Zn}$ & $b \mathrm{Co}$ & $b \mathrm{Mn}$ & $K_{\mathrm{i}} \mathrm{Cu}$ & $K_{\mathrm{i}} \mathrm{Zn}$ & $K_{\mathrm{i}} \mathrm{Co}$ & $K_{\mathrm{i}} \mathrm{Mn}$ \\
\hline$q_{\max } \mathrm{Cu}$ & 1.000 & & & & & & & & & & & \\
\hline$q_{\max } \mathrm{Zn}$ & 0.229 & 1.000 & & & & & & & & & & \\
\hline$q_{\max } \mathrm{Co}$ & 0.320 & 0.890 & 1.000 & & & & & & & & & \\
\hline$q_{\max } \mathrm{Mn}$ & 0.230 & 0.907 & 0.995 & 1.000 & & & & & & & & \\
\hline$b \mathrm{Cu}$ & -0.811 & -0.629 & -0.479 & -0.430 & 1.000 & & & & & & & \\
\hline$b \mathrm{Zn}$ & -0.051 & -0.969 & -0.765 & -0.801 & 0.553 & 1.000 & & & & & & \\
\hline$b \mathrm{Co}$ & -0.107 & -0.887 & -0.976 & -0.992 & 0.323 & 0.798 & 1.000 & & & & & \\
\hline$b \mathrm{Mn}$ & -0.367 & -0.939 & -0.989 & -0.984 & 0.584 & 0.828 & 0.956 & 1.000 & & & & \\
\hline$K_{\mathrm{i}} \mathrm{Cu}$ & 0.826 & -0.308 & -0.060 & -0.159 & -0.350 & 0.502 & 0.257 & 0.072 & 1.000 & & & \\
\hline$K_{\mathrm{i}} \mathrm{Zn}$ & 0.663 & -0.575 & -0.438 & -0.525 & -0.217 & 0.691 & 0.615 & 0.428 & 0.917 & 1.000 & & \\
\hline$K_{\mathrm{i}} \mathrm{Co}$ & 0.775 & -0.433 & -0.246 & -0.342 & -0.316 & 0.590 & 0.440 & 0.244 & 0.978 & 0.979 & 1.000 & \\
\hline$K_{\mathrm{i}} \mathrm{Mn}$ & 0.428 & -0.685 & -0.719 & -0.781 & -0.133 & 0.698 & 0.853 & 0.675 & 0.668 & 0.907 & 0.807 & 1.000 \\
\hline
\end{tabular}

a) Italics, correlation statistically significant.

Table 4 Statistically significant differences $(P<0.05)$ in $q_{\max }$ values of microelement cations in the examined systems

\begin{tabular}{|c|c|c|c|c|c|c|c|}
\hline \multicolumn{2}{|c|}{$\mathrm{Cu}(\mathrm{II})$} & \multicolumn{2}{|c|}{$\mathrm{Zn}(\mathrm{II})$} & \multicolumn{2}{|c|}{$\mathrm{Co}(\mathrm{II})$} & \multicolumn{2}{|c|}{$\operatorname{Mn}(\mathrm{II})$} \\
\hline System & $P$ value & System & $P$ value & System & $P$ value & System & $P$ value \\
\hline $4-2$ & 0.02640 & $3-2$ & 0.00129 & $3-2$ & 0.000262 & $3-2$ & 0.00361 \\
\hline- & - & - & - & $5-2$ & 0.000277 & $5-2$ & 0.01450 \\
\hline
\end{tabular}

Taking $\mathrm{Cu}$ (II) cations as an example, the effects of the anions and also of the physicochemical properties of the adsorbed metal cations on the biosorption properties of $E n$ teromorpha prolifera were explained. Comparing the values of $q_{\max }$ of macroalga towards $\mathrm{Cu}$ (II) cations, calculated from the Langmuir equation, it can be seen that the highest maximum biosorption capacity was obtained in system No.2: 31.9 $\mathrm{mg} \mathrm{g}^{-1}\left(\mathrm{SO}_{4}^{2-}\right.$ only) and the lowest was obtained in system No.5: $19.9 \mathrm{mg} \mathrm{g}^{-1}\left(\mathrm{Cl}^{-}\right.$only). This could be explained by the hypothesis that with increasing concentrations of chlorides in the solution, $q_{\max }$ of Enteromorpha prolifera towards $\mathrm{Cu}$ (II) cations decreased. In the literature, it has been reported that among all the investigated anions, $\mathrm{Cl}^{-}$ions form the most stable complexes with the examined metal ions [19]. In Figure 4, the effects of increasing concentrations of $\mathrm{Cl}^{-}$and $\mathrm{SO}_{4}{ }^{2-}$ anions on the biosorption capacity of $\mathrm{Cu}(\mathrm{II})$ cations are presented. It was found that with increasing amounts of chloride anions in the solution, qmax of the $\mathrm{Cu}$ (II) cations decreased linearly $(R=0.845)$, and with increasing amounts of sulfate anions, $q_{\max }$ of the $\mathrm{Cu}$ (II) cations increased linearly $(R=0.955)$.

As mentioned above, biosorption of microelement cations by algae could be influenced not only by the type of anion and its concentration in the solution, but also by the physicochemical properties of the adsorbed metal ions. The high affinity of Enteromorpha prolifera for $\mathrm{Cu}(\mathrm{II})$ cations could result from the ionic characteristics of $\mathrm{Cu}(\mathrm{II})$. Nieboer and McBryde et al. [20] proposed a covalent index, which was calculated using the equation:

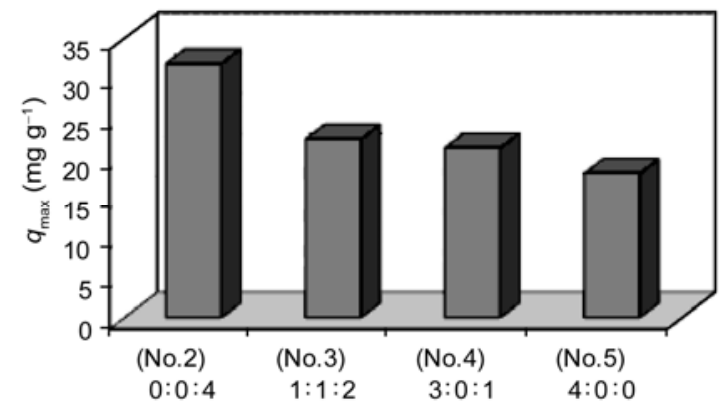

Figure 4 Effect of increasing anion concentrations on biosorption capacity of Enteromorpha prolifera towards $\mathrm{Cu}(\mathrm{II})$ cations.

Covalent index $=X_{m}^{2}(I R+0.85)$,

where $X_{m}$ represents the electronegativity of the ion, $I R$ is the ionic radius, and 0.85 is a constant assumed to reflect the ionic radii of $\mathrm{O}$ and $\mathrm{N}$ donor atoms. In general, the greater the covalent index of the metal ion, the greater is its potential to form covalent bonds with biological ligands such as carboxyl, hydroxyl, amino, and sulfhydryl groups on the biomass surface, and the higher is its biosorption capacity. The covalent indexes of the four metal cations studied are in the order $\mathrm{Cu}(\mathrm{II})>\mathrm{Co}(\mathrm{II})>\mathrm{Zn}(\mathrm{II})>\mathrm{Mn}$ (II) $(5.70>5.65>4.36>3.65)$ [21], and the order of the $q_{\max }$ values of Enteromorpha prolifera in system No.2 is $\mathrm{Cu}(\mathrm{II})>\mathrm{Co}(\mathrm{II})>\mathrm{Zn}$ (II) $>\mathrm{Mn}$ (II) $\left(0.502 \mathrm{mmol} \mathrm{g}^{-1}>0.166\right.$ mmol g${ }^{-1}>0.157 \mathrm{mmol} \mathrm{g}^{-1}>0.142 \mathrm{mmol} \mathrm{g}^{-1}$, determined using the Langmuir equation).

Moreover, among all the microelements studied, $\mathrm{Cu}(\mathrm{II})$ 
cations were characterized by the lowest value of $\left|\log K_{\mathrm{OH}}\right|$ (the absolute value of the logarithm of the first hydrolysis constant; $\left|\log K_{\mathrm{OH}}\right|: \operatorname{Mn}(\mathrm{II}), 10.6 ; \mathrm{Co}(\mathrm{II}), 9.7 ; \mathrm{Zn}(\mathrm{II}), 9.0$; $\mathrm{Cu}(\mathrm{II}), 8.0$ [21]), which reflects the affinity of metal ions towards ligands [22]. With increasing $\left|\log \mathrm{K}_{\mathrm{OH}}\right|, q_{\max }$ decreased (e.g., in system No.2, $q_{\max }$ of the $\mathrm{Cu}$ (II) cations was three times higher than that of the Mn(II) cations, determined using the modified Langmuir equation). Nevertheless, it was found that there was a linear relationship in each system studied between $q_{\max }$ (from the modified Langmuir equation) and $\left|\log \mathrm{K}_{\mathrm{OH}}\right|$ : No.2, $R=0.894$; No.3, $R=0.953$; No.4, $R=0.966$; and No.5, $R=0.963$.

In the literature, there are several papers which discuss the effects of anion concentrations on the biosorption capacity in multi-metal systems. Filipović-Kovačević et al. [10] examined the influence of anion concentrations $\left(\mathrm{NO}_{3}{ }^{-}\right.$, $\mathrm{SO}_{4}{ }^{2-}$, and $\mathrm{Cl}^{-}$) on the removal efficiency of the fungus Aspergillus niger towards $\mathrm{Cr}(\mathrm{VI}), \mathrm{Co}(\mathrm{II}), \mathrm{Ni}(\mathrm{II})$, and $\mathrm{Zn}(\mathrm{II})$ ions. To three solutions each containing $5.0 \mathrm{mg} \mathrm{L}^{-1}$ of $\mathrm{Cu}(\mathrm{II})$ and $\mathrm{Zn}(\mathrm{II})$ cations, and $10.0 \mathrm{mg} \mathrm{L}^{-1}$ of $\mathrm{Ni}(\mathrm{II})$ and $\mathrm{CrO}_{4}{ }^{2-}$ ions ( $\mathrm{pH} 5.0$ ), $50 \mathrm{mg} \mathrm{L}^{-1}$ of $\mathrm{NO}_{3}{ }^{-}, \mathrm{SO}_{4}{ }^{2-}$, and $\mathrm{Cl}^{-}$anions were separately added. The presence of $\mathrm{NO}_{3}{ }^{-}$or $\mathrm{SO}_{4}{ }^{2-}$ anions did not significantly influence the removal efficiencies of the examined ions. In contrast, the presence of $\mathrm{Cl}^{-}$anions significantly decreased the efficiency of metal ion biosorption in the multi-metal systems (a decrease of more than $50 \%$ in the presence of $\mathrm{Cl}^{-}$ions).

Kuyucak and Volesky [13] investigated the simultaneous effects of increasing the concentration $\left(0\right.$ to $\left.1000 \mathrm{mg} \mathrm{L}^{-1}\right)$ of anions $\left(\mathrm{NO}_{3}{ }^{-}, \mathrm{SO}_{4}{ }^{2-}, \mathrm{PO}_{4}{ }^{3-}\right.$, and $\left.\mathrm{CO}_{3}{ }^{2-}\right)$ in the solution on the biosorption of $\mathrm{Co}$ (II) cations by a dead marine brown macroalga, Ascophylum nodosum. The presence of $\mathrm{SO}_{4}{ }^{2-}$ and $\mathrm{PO}_{4}{ }^{3-}$ anions in a $\mathrm{Co}(\mathrm{II})$ solution at $\mathrm{pH} 4.5 \mathrm{did}$ not result in any change in biosorption, but $\mathrm{CO}_{3}{ }^{2-}$ suppressed the $\mathrm{Co}$ (II) uptake capacity of the biosorbent by $4 \%-14 \% . \mathrm{NO}_{3}{ }^{-}$ anions proved to be the strongest inhibitor of biosorptive Co(II) uptake, leading to approximately $35 \%$ suppression. In the case of the macroalga examined in our study, i.e., Enteromorpha prolifera, inhibition of the absorption of Co(II) cations was observed in system No.3, where the $\mathrm{Co}(\mathrm{II})$ is derived from $\mathrm{Co}\left(\mathrm{NO}_{3}\right)_{2} \cdot 6 \mathrm{H}_{2} \mathrm{O}$, in contrast to system No.2, in which $\mathrm{Co}$ (II) was present as $\mathrm{CoSO}_{4} \cdot 7 \mathrm{H}_{2} \mathrm{O}$. In system No.2, there was no inhibition of $\mathrm{Co}(\mathrm{II})$ ions, because all the cations were presented in the solution as a $\mathrm{SO}_{4}{ }^{2-}$.

As mentioned above, the effects of anions on biosorption capacity also differ for various biosorbents. For example, Ahuja et al. [11] observed the following inhibitory order of anions on $\mathrm{Zn}$ (II) cation biosorption by the cyanobacterium Oscillatoria anguistissim: $\mathrm{SO}_{4}{ }^{2-}>\mathrm{Cl}^{-}>\mathrm{NO}_{3}{ }^{-} . \mathrm{SO}_{4}{ }^{2-}$ and $\mathrm{Cl}^{-}$ ions in the concentration range $0-10 \mathrm{mmol} \mathrm{L}^{-1}$ decreased $\mathrm{Zn}(\mathrm{II})$ biosorption by factors of seven and two, respectively, whereas $\mathrm{NO}_{3}{ }^{-}$ions did not affect the biosorption of $\mathrm{Zn}(\mathrm{II})$ to any significant extent (decreased by 10.5\%). Also, Tobin et al. [12] observed inhibition of $\mathrm{La}(\mathrm{III}), \mathrm{Cd}(\mathrm{II}), \mathrm{Pb}$ (II), and $\mathrm{Ag}(\mathrm{I})$ cations uptake by the fungus Rhizopus arrhizus in the presence of anions in the solution. No anion was found to enhance metal uptake levels, and the degree of inhibition generally followed the order EDTA $>\mathrm{SO}_{4}{ }^{2-}>\mathrm{Cl}^{-}>\mathrm{PO}_{4}{ }^{3-}>$ glutamate $>\mathrm{CO}_{3}{ }^{2-}$.

\section{Conclusion}

The performed experiments on biosorption of microelement cations in single- and multi-metal systems showed that in the single-metal system the type of anion has no significant influence on biosorption capacity, but in the multi-metal systems, differences were seen. The maximum biosorption capacity of Enteromorpha prolifera towards $\mathrm{Co}(\mathrm{II})$ cations decreased in the sequence $\mathrm{Cl}^{-}\left(46.0 \mathrm{mg} \mathrm{g}^{-1}\right)>\mathrm{SO}_{4}{ }^{2-}(42.8$ $\left.\mathrm{mg} \mathrm{g}^{-1}\right)>\mathrm{NO}_{3}^{-}\left(41.9 \mathrm{mg} \mathrm{g}^{-1}\right)$. The differences in $q_{\max }$ values were not statistically significant because the value of $\mathrm{VC}$ was smaller than $10 \%(4.95 \%)$. The opposite situation was observed in multi-metal systems. It was confirmed that the differences in the values of $q_{\max }$ for each microelement cation were statistically significant. For $\mathrm{Cu}(\mathrm{II}), \mathrm{Zn}(\mathrm{II})$, $\mathrm{Co}$ (II), and $\mathrm{Mn}$ (II) cations, statistically significant differences were observed between systems No.2 $\left(\mathrm{Cl}^{-}: \mathrm{NO}_{3}^{-}\right.$: $\left.\mathrm{SO}_{4}{ }^{2-}=0: 0: 4\right)$ and No.5 $\left(\mathrm{Cl}^{-}: \mathrm{NO}_{3}{ }^{-}: \mathrm{SO}_{4}{ }^{2-}=4: 0: 0\right)$.

During simultaneous biosorption of $\mathrm{Cu}(\mathrm{II}), \mathrm{Zn}(\mathrm{II}), \mathrm{Co}(\mathrm{II})$, and $\mathrm{Mn}(\mathrm{II})$ cations in systems No.3 $\left(\mathrm{Cl}^{-}: \mathrm{NO}_{3}{ }^{-}: \mathrm{SO}_{4}{ }^{2-}=\right.$ $1: 1: 2)$, No.4 $\left(\mathrm{Cl}^{-}: \mathrm{NO}_{3}{ }^{-}: \mathrm{SO}_{4}{ }^{2-}=3: 0: 1\right)$ and No.5 $\left(\mathrm{Cl}^{-}\right.$: $\left.\mathrm{NO}_{3}{ }^{-}: \mathrm{SO}_{4}{ }^{2-}=4: 0: 0\right)$, inhibition was observed. Therefore, a new modified Langmuir equation with inhibition was proposed. It was observed that the higher value of inhibition constant, the smaller inhibition of binding metal cations by macroalga is. In all examined systems, maximum biosorption capacity of Enteromorpha prolifera towards examined microelement cations was as follows: $\mathrm{Cu}(\mathrm{II})>\mathrm{Zn}(\mathrm{II})>$ $\mathrm{Co}(\mathrm{II})>\mathrm{Mn}$ (II) .

Using $\mathrm{Cu}(\mathrm{II})$ cations as an example, it was shown that $\mathrm{Cl}^{-}$anions decreased the efficiency of metal ion biosorption in multi-metal systems to the largest extent. The highest value of $q_{\max }$ was obtained in system No.2, $31.9 \mathrm{mg} \mathrm{g}^{-1}$ $\left(\mathrm{SO}_{4}{ }^{2-}\right.$ only) and the smallest in system No.5, $19.9 \mathrm{mg} \mathrm{g}^{-1}$ $\left(\mathrm{Cl}^{-}\right.$only). The total quantities bound by the Enteromorpha prolifera biomass were as follows: system No.3 $(1: 1: 2)$, $1.25 \mathrm{mmol} \mathrm{g}^{-1}$ of $\mathrm{Cu}(\mathrm{II}), \mathrm{Zn}(\mathrm{II}), \mathrm{Co}(\mathrm{II})$, and $\mathrm{Mn}(\mathrm{II})$ cations, in No.2 (0:0:4), $1.12 \mathrm{mmol} \mathrm{g}^{-1}$, in No.5 (4:0:0), 1.03 $\mathrm{mmol} \mathrm{g}^{-1}$, and in No.4 (3:0:1), only $0.761 \mathrm{mmol} \mathrm{g}^{-1}$. These results indicated that future experiments should be performed using different anions (No.3) or $\mathrm{SO}_{4}{ }^{2-}$ (No.2). However, system No.2 is more beneficial if the economic aspects are taken into account because microelements in the form of sulfates are much cheaper than those in the form of chlorides or nitrates.

This work was supported by the Polish Ministry of Science and Higher Education (R05 01401 and N N209 146136). 
1 Abu Al-Rub F A, El-Naas M H, Ashour I, et al. Biosorption of copper on Chlorella vulgaris from single, binary and ternary metal aqueous solutions. Process Biochem, 2006, 41: 457-464

2 Pagnanelli F, Trifoni M, Beolchini F, et al. Equilibrium biosorption studies in single and multi-metal systems. Process Biochem, 2001, 37: $115-124$

3 Aksu Z, Dönmez G. Binary biosorption of cadmium(II) and nickel(II) onto dried Chlorella vulgaris: Co-ion effect on mono-component isotherm parameters. Process Biochem, 2006, 41: 860-868

4 Mohapatra H, Gupta R. Concurrent sorption of $\mathrm{Zn}(\mathrm{II}), \mathrm{Cu}(\mathrm{II})$ and $\mathrm{Co}$ (II) by Oscillatoria angustissima as a function of $\mathrm{pH}$ in binary and ternary metal solutions. Bioresour Technol, 2005, 96: 1387-1398

5 Pradhan S, Rai L C. Biotechnological potential of Microcystis sp. in $\mathrm{Cu}, \mathrm{Zn}$ and $\mathrm{Cd}$ biosorption from single and multimetallic systems. BioMetals, 2001, 14: 67-74

6 Chong K H, Volesky B. Metal biosorption equilibria in a ternary system. Biotechnol Bioeng, 1996, 49: 629-638

7 Michalak I, Chojnacka K. The application of macroalga Pithophora varia Wille enriched with microelements by biosorption as biological feed supplement for livestock. J Sci Food Agric, 2008, 88: 1178-1186

8 Han X, Wong Y S, Wong M H, et al. Effects of anion species and concentration on the removal of $\mathrm{Cr}(\mathrm{VI})$ by a microalgal isolate, Chlorella miniata. J Hazard Mater, 2008, 158: 615-620

9 Pulsawat W, Leksawasdi N, Rogers P L, et al. Anions effects on biosorption of $\mathrm{Mn}$ (II) by extracellular polymeric substance (EPS) from Rhizobium etli. Biotechnol Lett, 2003, 25: 1267-1270

10 Filipović-Kovačević Ž, Sipos L, Briški F. Biosorption of chromium, copper, nickel and zinc ions onto fungal pellets of Aspergillus niger 405 from aqueous solutions. Food Technol Biotechnol, 2000, 38: 211-216

11 Ahuja P, Gupta R, Sabena R K. $\mathrm{Zn}^{2+}$ biosorption by Oscillatoria an- guistissima. Process Biochem, 1999, 34: 77-85

12 Tobin J M, Cooper D G, Neufeld R J. Influence of anions on metal adsorption by Rhizopus arrhizus biomass. Biotechnol Bioeng, 1987, 30: $882-886$

13 Kuyucak N, Volesky B. Accumulation of cobalt by marine alga. Biotechnol Bioeng, 1989, 33: 809-814

14 Michalak I, Chojnacka K. The new application of biosorption properties of Enteromorpha prolifera. Appl Biochem Biotechnol, 2010, 160: 1540-1556

15 Michalak I, Chojnacka K. Edible macroalga Ulva prolifera as microelemental feed supplement for livestock: The fundamental assumptions of the production method. World J Microbiol Biotechnol, 2009, 25: 997-1005

16 Chojnacka K. The application of multielemental analysis in the elaboration of technology of mineral feed additives based on Lemna minor biomass. Talanta, 2006, 70: 966-972

17 Langmuir I. The adsorption of gases on plane surfaces of glass, mica and platinum. J Am Chem Soc, 1918, 40: 1361-1403

18 Ostasiewicz S, Rusnak Z, Siedlecka U. Statystyka, elementy teorii i zadania (in Polish). Wrocław: Wydawnictwo AE im. Oskara Langego we Wrocławiu, 2001

19 Sillen L G, Martell A E. Stability Constants of Metal-Ion Complexes. London: The Chemical Society, 1964

20 Nieboer E, McBryde W A E. Free energy relationships in coordinate chemistry (III): A comprehensive index to complex stability. Can J Chem, 1973, 51: 2512-2524

21 Chen C, Wang J L. Correlating metal ionic characteristics with biosorption capacity using QSAR model. Chemosphere, 2007, 69: 1610-1616

22 Baes C F, Mesmer R. The Hydrolysis of Cations. New York: John Wiley, 1976

Open Access This article is distributed under the terms of the Creative Commons Attribution License which permits any use, distribution, and reproduction in any medium, provided the original author(s) and source are credited. 